\title{
Therapy of anorexia and Young's early maladaptive schemas. Longitudinal study
}

\author{
Dorota Macik $^{1 \cdot A, C, D, E, F}$, Ewa Sas ${ }^{2 \cdot B}$ \\ 1: Institute of Psychology, John Paul II Catholic University of Lublin, Lublin, Poland \\ 2: Faculty of Psychology, University of Finance and Management, Warsaw, Poland
}

\section{BACKGROUND}

Young's early maladaptive schemas are defined as convictions about oneself acquired in childhood, formed by a child in response to deprivation of his or her basic needs, especially in the area of relationships. In the case of anorexia, the role of the family and relations is emphasized as crucial for the genesis of this disorder. The aim of the research was to investigate whether Young's early maladaptive schemas change during the therapy, which would prognosticate higher treatment efficiency.

\section{PARTICIPANTS AND PROCEDURE}

The study group included 30 women suffering from anorexia, starting their 6-week therapeutic program. The procedure included double measurement: during the administration and discharge. The respondents filled in the Young Schema Questionnaire in its short form (YSQ-S3) (twice), the Acceptance of Illness Scale (AIS) adapted by Juczyński (twice), and a demographic chart (once).

\section{RESULTS}

The intensity of all schemas decreased after completion of the therapeutic program; the differences were mostly statistically significant. The composition of the most intense schemas did not change significantly: unrelenting standards and abandonment were the highest during both measurements. What changed were the interrelations between the schemas. They are also connected with the acceptance of the illness (the weaker they are, the greater the acceptance, and the stronger the relations) and with psychological well-being, especially during the post-therapy measurement.

\section{CONCLUSIONS}

The schemas seem to be significant from the perspective of understanding anorexia. They are susceptible to be changed by integrative therapies. Nevertheless, it seems that in order to achieve a durable change, schema therapy should be applied.

\section{KEY WORDS}

acceptance of illness; early maladaptive schemas; anorexia nervosa; follow-up study; therapy

Corresponding author - Dorota Mącik, Ph.D., Institute of Psychology, John Paul Il Catholic University of Lublin,

14 Racławickie Avenue, 20-950 Lublin, Poland, e-mail: dorota_macik@tlen.pl

AUthors' CONTRIBUtion - A: Study design - B: Data collection - C: Statistical analysis - D: Data interpretation .

E: Manuscript preparation · F: Literature search · G: Funds collection

TO CITE THIS ARTICLE - Mącik, D., \& Sas, E. (2015). Therapy of anorexia and Young's early maladaptive schemas.

Longitudinal study. Current Issues in Personality Psychology, 3(4), 203-213.

RECEIVED 15.07.2015 - REVIEWED 07.09.2015 - ACCEPTED 29.09.2015 - PUBLISHED 12.10.2015 


\section{BACKGROUND}

The problem of eating disorders is becoming more and more common in the modern world. A constant increase in the number of anorectics is also observed in Poland (Eder, Stawczyk, Lehmann, Jankowiak, \& Cichy, 2007; Hoek, 1998). In addition, it is emphasized that anorexia nervosa (AN) has the highest mortality rate among all mental disorders (Hoek, 1998; Bator, Bronkowska, Ślepecki, \& Biernat, 2011). Assuming that in most cases treatment is administered at some point, this rate suggests low susceptibility of anorectics to treatment. Former studies have not provided an unequivocal assessment of treatment efficiency; most specialists write about numerous therapeutic difficulties (Stochel \& Janas-Kozik, 2010). To a high extent, the difficulties result from the egosyntonic nature of the symptoms (Starzomska, 2008). Another obstacle is convincing patients that they do need the illness and that they acquire numerous benefits from being ill (Talarczyk, 2009).

The therapeutic perspective has to embrace all causes of anorexia - both biological (Przewoźnik, 2013) and cultural (Jośko \& Kamecka-Krupa, 2007), but also personality- and family of origin-related. Such families are described as stiff, emotionally cold, demanding a lot from the children and at the same time impeding separation and the achievement of healthy autonomy (Jośko \& Kamecka-Krupa, 2007; Palus, 2006).

The idea of the impact of a family on the mental development and further difficulties in functioning was discussed in studies by Jeffrey Young (Young, 1999; Young, Rygh, Weinberger, \& Beck, 2008; Young, Klosko, \& Weishaar, 2014). He claims that failure to satisfy certain basic psychological needs of a child (e.g. of attention, acceptance, unconditional love, but also fun or setting limits) leads to the development of self-convictions related to the deprived need. For example a child, whose parents neglect him or her, develops the conviction 'I am unimportant', 'I have to try harder', etc. Such an assessment makes a child seek ways to cope with this conviction, in order to avoid negative emotions related thereto (Muris, 2006; Young et al., 2014). In this context, the role of a family is similar to the role ascribed to a family in the genesis of anorexia.

Depending on the kind of the deprived need, Young differentiated 18 convictions, which he called early maladaptive schemas (EMS) (Young et al., 2014; Brummett, 2008; Young, 1999). The convictions were divided into five areas (domains), depending on the type of the family of origin:

1. Disconnection and Rejection - the typical family of origin is cold and alienated from feelings, unpredictable, abusive (schemas: abandonment/instability, mistrust/abuse, emotional deprivation, defectiveness/shame, social isolation).
2. Impaired Autonomy and Performance - the family eviscerates the child's self-confidence, does not bolster successes, is overprotective, the relations can be blurred (schemas: dependence/incompetence, vulnerability to harm or illness, undeveloped self, failure to achieve).

3. Impaired Limits - the family has no rules or limits, strengthens the child's uniqueness excessively, avoids frustration and confrontation with stress (schemas: entitlement/grandiosity, insufficient selfcontrol).

4. Other Directedness - the family shows conditional love, the child forgoes his or her own needs to gain attention and acceptance (schemas: subjugation, self-sacrifice, approval-seeking).

5. Overvigilance and inhibition - the typical family of origin is punitive, its focus is on success and adherence to its rules, emotions are perceived as unsolicited (schemas: negativity/pessimism, emotional inhibition, unrelenting standards, punitiveness) (Young et al., 2014).

In Poland few studies have been conducted on the schemas, especially concerning their empirical verification in terms of their intensity and structure in the case of disorders from Axis I and II (DSM-IV-TR), and also in the non-clinical population. The presented research showcases some of the major studies conducted on the schemas and their correlates in various disorders.

The aim of this study was an initial verification of the intensity and structure of the most severe schemas in women with eating disorders of the anorectic kind. Apart from that, susceptibility to change of the early maladaptive schemas was verified, under the influence of therapeutic experience excluding a schema-focused therapy. The study group included girls suffering from anorexia, staying in an in-patient therapeutic center. The center offers a therapeutic program for the treatment of eating disorders in 6-week cycles. The aim of the therapy is to work on emotions, relations and feelings, and less on the illness symptoms themselves, which should lead to the root of the disease to some extent. This assumption is compatible with the idea of the schema-focused therapy. The therapy in the center is led individually (a systemic approach focused on the analysis of family relations and emotions and on the illness representation; a cognitive-behavioral approach focused on the analysis of dysfunctional convictions and thoughts and their reformulation into more functional ones; this approach also uses integrative assumptions of other therapies) and in groups. The work includes elements of art therapy, psychoeducation and dietary classes. An additional element is the systemic family therapy. Such assumptions underlying the work with patients seem to be compatible with what is done when working on the schemas: seeking reasons, getting through to emotions, ana- 
lyzing relations and their nature, working on relations, referring convictions related to them to oneself and one's self-esteem, which may decrease the severity of the dominating schemas and weaken them. Of course it should be assumed that these changes will not be dramatic. The schema-focused therapy usually takes one to two years, if acting in accordance with the suggested techniques (Young et al., 2014). In the center the therapeutic work is very intense; nevertheless it takes only 6 weeks, which is too short to change the schemas; in addition the schemas are not identified and are not addressed directly. However, it seems that some basic assumptions taken in the center may change their severity.

Due to this, the following research questions were formulated: RQ1: What is the intensity and combination of the dominating schemas with anorectics? RQ2: Do the schemas change under the influence of the 6-week therapy, and what is the nature of the changes? RQ3: What are the relations between the schemas and the illness acceptance, and do they change with time? RQ4: What are the relations between the schemas and the perception of one's own physical and mental well-being and the subjective assessment of one's own life, and do these relations change under the influence of the therapy? Due to the exploratory and initial nature of the research, the authors decided not to formulate any hypotheses and stop at the questions.

\section{PARTICIPANTS, PROCEDURE, AND MEASURES}

In order to verify the above questions, the authors carried out research in the in-patient center, where the therapy of anorexia was conducted. The study group included 30 women, who had been diagnosed with anorexia (without differentiating its subtypes), qualified to begin a 6-week therapeutic program. The patients were aged 15 to 31 years, with the average age of 22 years; $36 \%$ of them were still attending school/college. Approximately $63 \%$ of them lived in a town or a city. They described their material status as at least average (50\%) or better $(43 \%)$, with only $7 \%$ describing it as bad. Approximately $33 \%$ of the patients were in a relationship, with $13 \%$ married; the others had no partner. None of the patients had children. Eighty-three percent of them described themselves as believers. For the majority of the patients their stay in the center was another therapeutic attempt. The duration of the illness differed among the patients, ranging from 1 to 14 years.

The research procedure included a double measurement - an examination immediately after the administration to the center, before the implementation of any therapeutic activities (hereinafter referred to as measurement 1 - M1) and an examination after the completion of the therapeutic program, immediately before discharging the patient (measurement 2 - M2). The same methods were used during both measurements, with the exception of the informative chart, which was filled in as a whole only during the administration, and during the discharge only three questions taken from this chart were asked: What is currently your physical well-being? What is currently your mental well-being? How would you evaluate your life? Answers were given on a 7-point scale, where 1 means very bad and 7 means very good.

In addition, the following research tools were used: 1. Young Schema Questionnaire - Short Form 3, YSQ-S3 (Calvete, Orue, \& González-Diez, 2013; Hawke \& Provencher, 2012; Kriston, Schäfer, Jacob, Härter, \& Hölzel, 2013; Young et al., 2014). The Polish version is currently being reviewed. Justyna Oettingen, who owns the copyright of the questionnaire in Poland, translated it and prepared a draft version. She consented to the use of the questionnaire for the purpose of this study. The scale consists of 90 statements. A respondent has to refer to each of them on a 6-point scale. The statements measure 18 Young schemas, grouped into 5 domains. All calculations were done on raw results (the average was not calculated for the scale results), due to which the minimum for a schema is 5 , the maximum 30 , and for the whole scale: 90 540. Scale reliability measured with Cronbach's $\alpha$ coefficient equaled: for M1: from .89 for Entitlement to .96 for Mistrust, and for M2: from .79 for Entitlement to .95 for Emotional deprivation.

2. Acceptance of Illness Scale (AIS) by Felton, Revenson and Hinrichsen, Polish adaptation by Zygfryd Juczyński (Juczyński, 1999, 2001). The scale consists of 8 statements describing the consequences of bad health condition in terms of limitations, dependencies and decreased self-esteem. The higher the result, the greater the acceptance of the illness and recognition of opportunities to function well beyond the illness. Scale reliability (Polish version) measured with Cronbach's $\alpha$ coefficient equaled .85 (Juczyński, 2001, p. 168).

\section{RESULTS}

At the beginning the severity of schemas during both measurements was assessed and the most intense ones were identified. Basic descriptive statistics for schemas are presented in Table 1. Average ones are presented in Figure 1.

During the first measurement the most severe schemas were: abandonment/instability, unrelenting standards, social isolation, punitiveness, defectiveness/shame. During the second measurement the combination was slightly different: unrelenting standards, abandonment/instability, negativism, pu- 
Table 1

Basic statistics and values of differences between the measurements for early maladaptive schemas

\begin{tabular}{|c|c|c|c|c|c|c|c|c|c|c|}
\hline \multirow[t]{2}{*}{ Schemas } & \multicolumn{4}{|c|}{ Measurement 1} & \multicolumn{4}{|c|}{ Measurement 2} & \multirow[t]{2}{*}{$t$} & \multirow[t]{2}{*}{$p$} \\
\hline & Min & Max & $M$ & $S D$ & Min & Max & $M$ & $S D$ & & \\
\hline Emotional deprivation & 5.00 & 27.00 & 13.20 & 6.16 & 6.00 & 28.00 & 12.20 & 4.75 & 1.06 & .298 \\
\hline Abandonment/instability & 10.00 & 30.00 & 23.20 & 6.53 & 8.00 & 30.00 & 20.60 & 6.95 & 2.75 & .010 \\
\hline Mistrust/abuse & 7.00 & 30.00 & 19.47 & 7.39 & 9.00 & 30.00 & 17.77 & 5.91 & 1.39 & .174 \\
\hline Social isolation & 10.00 & 30.00 & 22.70 & 5.97 & 7.00 & 28.00 & 18.07 & 5.94 & 4.26 & $<.001$ \\
\hline Defectiveness/shame & 7.00 & 30.00 & 21.07 & 6.73 & 6.00 & 29.00 & 16.87 & 5.99 & 3.51 & .002 \\
\hline Failure & 6.00 & 30.00 & 22.33 & 7.23 & 7.00 & 30.00 & 18.73 & 7.24 & 2.91 & .007 \\
\hline Dependence/incompetence & 5.00 & 30.00 & 20.10 & 6.40 & 5.00 & 25.00 & 16.57 & 5.12 & 3.71 & .001 \\
\hline Vulnerability to harm or illness & 7.00 & 25.00 & 14.67 & 5.11 & 5.00 & 27.00 & 13.30 & 5.97 & 1.60 & .119 \\
\hline Enmeshment/undeveloped self & 7.00 & 29.00 & 19.30 & 6.53 & 6.00 & 30.00 & 17.87 & 6.89 & 1.35 & .187 \\
\hline Subjugation & 6.00 & 30.00 & 20.67 & 5.56 & 7.00 & 30.00 & 18.63 & 5.88 & 2.06 & .049 \\
\hline Self-sacrifice & 6.00 & 29.00 & 18.87 & 5.69 & 6.00 & 30.00 & 18.63 & 7.24 & 0.22 & .826 \\
\hline Approval-seeking & 7.00 & 30.00 & 20.60 & 5.90 & 8.00 & 30.00 & 18.87 & 5.96 & 2.11 & .043 \\
\hline Grandiosity & 6.00 & 28.00 & 17.07 & 5.54 & 5.00 & 29.00 & 16.50 & 5.41 & 0.65 & .518 \\
\hline Insufficient self-control & 12.00 & 30.00 & 20.80 & 5.38 & 7.00 & 30.00 & 17.70 & 6.34 & 3.32 & .002 \\
\hline Emotional inhibition & 10.00 & 30.00 & 19.93 & 6.01 & 10.00 & 30.00 & 18.73 & 6.40 & 1.12 & .270 \\
\hline $\begin{array}{l}\text { Unrelenting standards/hy- } \\
\text { percriticalness }\end{array}$ & 14.00 & 30.00 & 23.17 & 4.85 & 10.00 & 30.00 & 21.53 & 6.43 & 2.15 & .040 \\
\hline Negativity/pessimism & 12.00 & 30.00 & 19.90 & 5.00 & 10.00 & 30.00 & 19.17 & 5.94 & 0.80 & .429 \\
\hline Punitiveness & 7.00 & 30.00 & 21.50 & 7.28 & 9.00 & 30.00 & 18.97 & 7.68 & 2.07 & .047 \\
\hline YSQ total & 226.00 & 515.00 & 358.77 & 74.21 & 181.00 & 487.00 & 320.70 & 77.85 & 3.12 & .004 \\
\hline
\end{tabular}

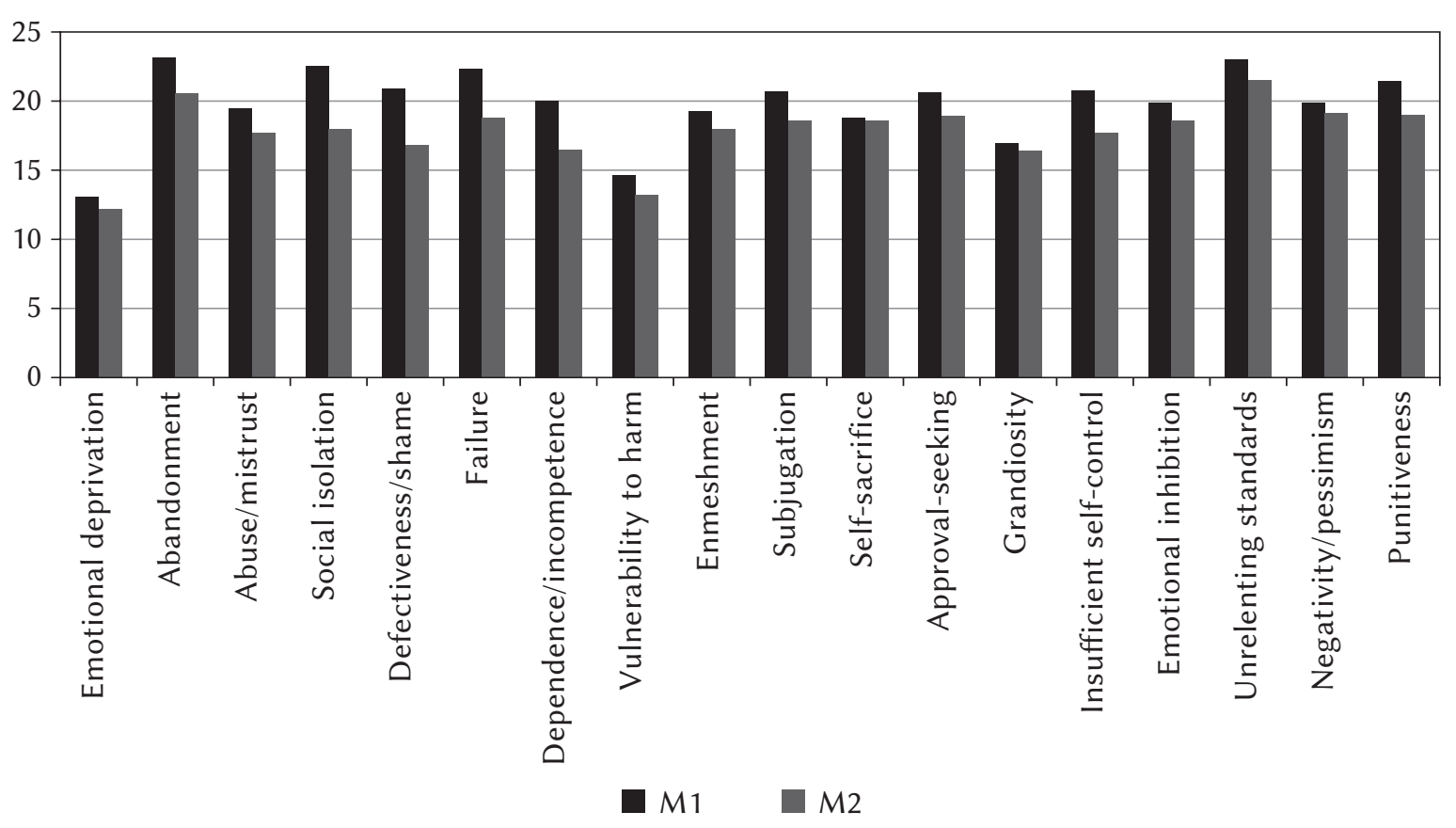

Figure 1. Diagrams of mean results for the schemas from two measurements. 
nitiveness, approval-seeking, failure. In addition, the intensity of all schemas during the second measurement was lower than during the first one, which indicates that the therapy provided in the center also affects early self-convictions.

Then it was investigated whether the observed changes were statistically significant. To check it, the test of the difference between means for dependent samples was performed. The results of the $t$-test and their significance are presented in Table 1 . These data indicate that the changes in early maladaptive schemas, achieved due to the therapy conducted in the center (despite its relatively short duration), reveal significant differences in the intensity of the majority of the schemas.

It was also evaluated, using the multidimensional scaling procedure PROXSCAL, how the interrelations between schemas changed. The measures of the goodness-of-fitting model to the empirical data during the first measurement equaled: STRESS $=.046$, Young's S-STRESS $=.079$, dispersion accounted for $=.95$; during the second measurement: STRESS $=.026$, Young's S-STRESS $=.056$, dispersion accounted for $=.97$. These results indicate that the two-dimensional model fits the empirical data well, which allows for its interpretation. The obtained results are presented in Figures 2 and 3.

The analysis of dispersion of the schemas from both measurements indicates that there are some interesting changes in the interrelation of subsequent schemas and in the relation between the schemas and the proposed dimensions. Patients became more independent from others and felt more valuable at the second measurement. An in-depth analysis with the description of the dimensions is presented in the discussion of the results.

Apart from that, illness acceptance was measured at the beginning and end of the therapy, alongside correlations between illness acceptance, physical and mental well-being and the assessment of one's life so far. Illness acceptance was compared using the t-test for dependent samples, and the correlations were calculated using Pearson's coefficient $r$. The obtained results are presented in Tables 2 and 3.

These analyses indicate that the level of illness acceptance increased along with the duration of the therapy. In addition, illness acceptance correlates significantly with some of the schemas; during the second measurement there were more correlations and they were stronger. It means that decreasing the

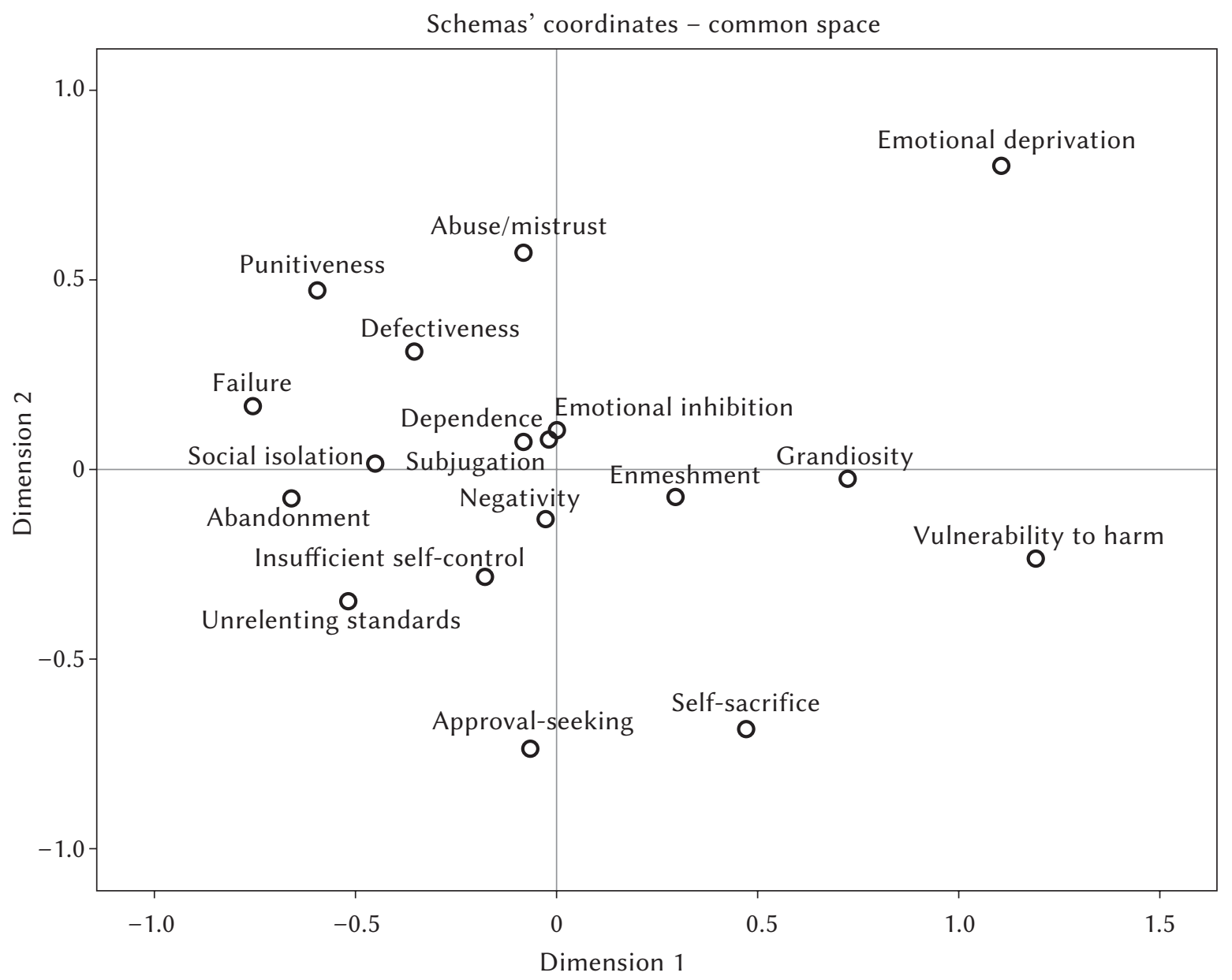

Figure 2. Results of multidimensional scaling PROXSCAL for schemas - measurement 1. 
Schemas' coordinates - common space

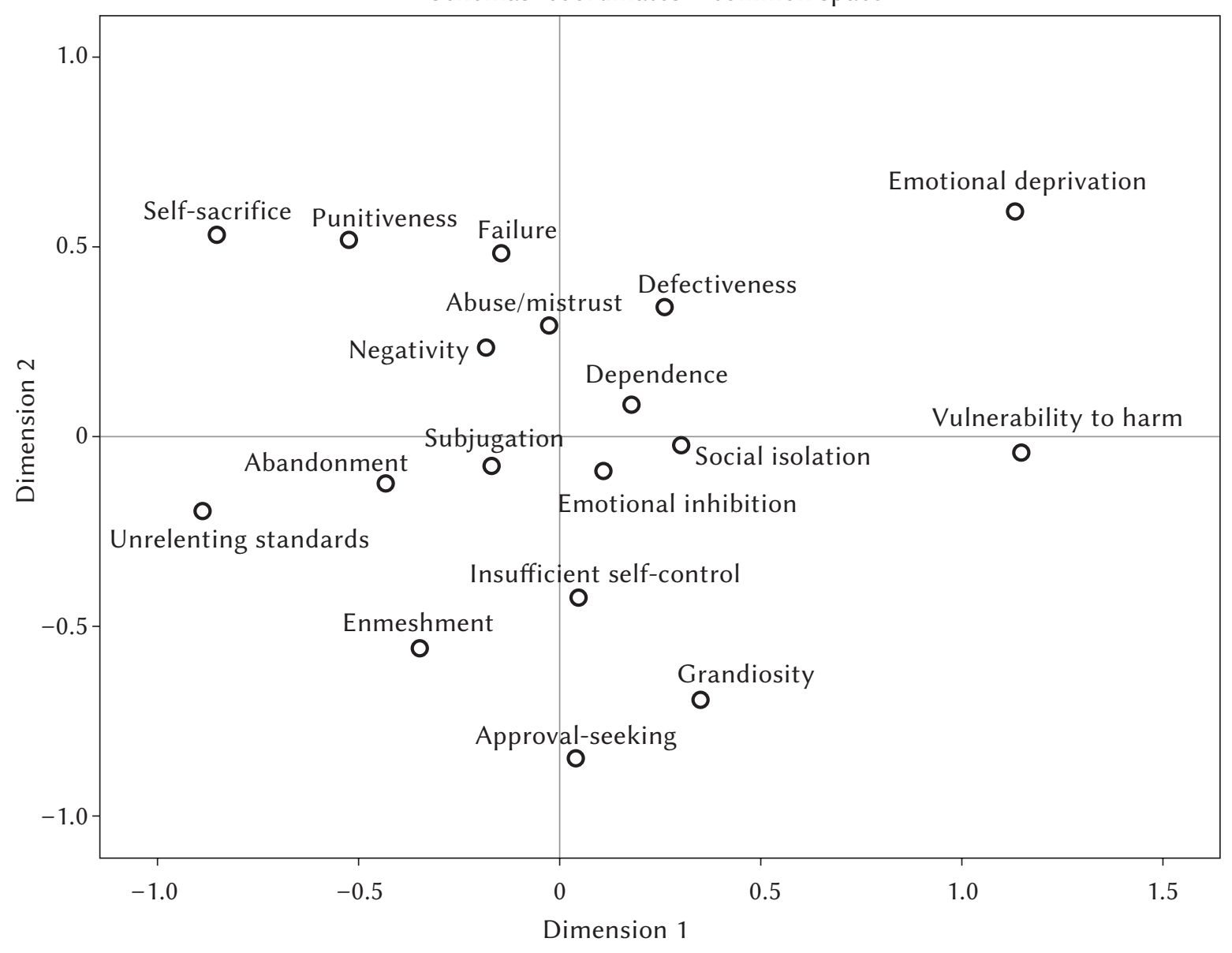

Figure 3. Results of multidimensional scaling PROXSCAL for schemas - measurement 2.

Table 2

Values of means and test of differences for the acceptance of illness, assessment of life and well-being

\begin{tabular}{|c|c|c|c|c|c|c|}
\hline & \multicolumn{2}{|c|}{ Measurement 1} & \multicolumn{2}{|c|}{ Measurement 2} & \multirow{2}{*}{$t$} & \multirow{2}{*}{$p$} \\
\hline & $M$ & $S D$ & $M$ & $S D$ & & \\
\hline AIS & 17.90 & 6.22 & 20.80 & 5.99 & 2.09 & .045 \\
\hline Physical health & 3.90 & 1.69 & 3.20 & 1.63 & 2.57 & .015 \\
\hline Mental well-being & 3.53 & 1.80 & 3.62 & 1.57 & -0.05 & .601 \\
\hline Assessment of life & 3.53 & 1.74 & 3.83 & 1.58 & -1.79 & .083 \\
\hline
\end{tabular}

severity of schemas increases illness acceptance. The patients seemed to recognize the relation between their convictions and their well-being, especially mental well-being - this refers mostly to the schemas concerning insufficient achievements and autonomy: the weaker the schemas, the better the mood. The significant positive correlation of the self-sacrifice schema and mental well-being during the first measurement is worth noting - the patients were deeply convinced that the more they forgo their own needs for the sake of others, the better they will function psychologically. During the second measurement that relation was insignificant. Correlations between schemas and physical well-being drew the authors' attention because of their unexpected positive sign; however they were insignificant, despite two schemas during the first measurement.

\section{DISCUSSION}

Analysis of data in addressing the first research question, RQ1: What is the intensity and combination of the dominating schemas with anorectics?, led to the assessment of the combination of schemas and their intensity during the two measurements. The initial schema 
Table 3

Values of correlation coefficients between the schemas and acceptance of illness, assessment of life and well-being

\begin{tabular}{|c|c|c|c|c|c|c|c|c|}
\hline \multirow[t]{2}{*}{ Schemas } & \multicolumn{4}{|c|}{ Measurement 1} & \multicolumn{4}{|c|}{ Measurement 2} \\
\hline & $\mathrm{Ph} w-\mathrm{b}$ & $M w-b$ & $\mathrm{AL}$ & AIS & Ph w-b & $M w-b$ & $\mathrm{AL}$ & AIS \\
\hline Emotional deprivation & .211 & -.007 & -.123 & $-.361^{*}$ & .088 & -.070 & -.235 & -.232 \\
\hline Abandonment/instability & .103 & .072 & -.063 & $-.499^{* *}$ & .129 & $-.412^{*}$ & -.160 & $-.537^{* *}$ \\
\hline Mistrust/abuse & .286 & .179 & .005 & -.226 & -.045 & -.299 & -.234 & $-.512^{* *}$ \\
\hline Social isolation & .287 & -.143 & -.337 & -.322 & .323 & -.290 & -.197 & $-.605^{* *}$ \\
\hline Defectiveness/shame & .207 & -.069 & -.227 & $-.478^{* *}$ & .300 & -.312 & -.192 & $-.701^{* *}$ \\
\hline Failure & .156 & $-.379^{*}$ & -.353 & -.302 & .116 & $-.386^{*}$ & -.279 & $-.600^{* *}$ \\
\hline Dependence/incompetence & .282 & -.136 & -.105 & $-.440^{*}$ & .127 & $-.425^{*}$ & -.218 & $-.613^{* *}$ \\
\hline Vulnerability to harm or illness & .335 & .178 & .160 & -.038 & .033 & $-.413^{*}$ & -.163 & -.258 \\
\hline Enmeshment/undeveloped self & $.390^{*}$ & .059 & .107 & $-.411^{*}$ & .165 & $-.411^{*}$ & -.066 & $-.363^{*}$ \\
\hline Subjugation & $.430^{*}$ & -.023 & -.002 & $-.451^{*}$ & .214 & -.349 & -.055 & $-.576^{* *}$ \\
\hline Self-sacrifice & .067 & $.382^{*}$ & .322 & .129 & .024 & -.152 & -.009 & -.304 \\
\hline Approval-seeking & .073 & .045 & -.139 & .013 & .209 & -.314 & -.061 & -.029 \\
\hline Grandiosity & .082 & .232 & .193 & .026 & .168 & -.191 & .055 & -.011 \\
\hline Insufficient self-control & -.072 & .099 & -.061 & -.187 & .120 & -.274 & -.174 & -.283 \\
\hline Emotional inhibition & .026 & -.213 & -.200 & -.312 & .168 & -.184 & -.049 & $-.467^{* *}$ \\
\hline Unrelenting standards & -.027 & .120 & -.151 & -.075 & .026 & -.216 & -.062 & -.223 \\
\hline Negativity/pessimism & .172 & -.109 & -.266 & -.094 & .021 & $-.395^{*}$ & -.299 & $-.431^{*}$ \\
\hline Punitiveness & .220 & .055 & -.012 & -.023 & .056 & -.184 & -.146 & $-.415^{*}$ \\
\hline YSQ total & .261 & .020 & -.113 & -.346 & .176 & $-.419^{*}$ & -.201 & $-.578^{* *}$ \\
\hline
\end{tabular}

Note. ${ }^{*} p<.05 ;{ }^{* *} p<.01 ; \mathrm{Ph}$ w-b - physical well-being, $\mathrm{M} \mathrm{w}$-b - mental well-being, AL - assessment of life, AIS - acceptance of illness.

combination (before commencing therapy, hence with a certain degree of probability, characteristic for anorexia) was abandonment, unrelenting standards, social isolation, failure, defectiveness and punitiveness. The intensity of all schemas is higher than the middle of the theoretical range of results (above 15 in raw results). It means that the schemas are rooted deeply. Their combination conjures an image of a person who is convinced that significant figures are unpredictable and close relations are doomed to break up, so there is no point in getting involved in them. Such a person is also certain that he has to try harder and harder, because he is never good enough; meanwhile he does not believe that he can achieve as much as his peers in any area, because in fact he is stupid, not talented, worthless. He may feel so imperfect that he has to hide it from others, so that they do not find out what he is really like, as otherwise he would never gain their attention and acceptance. All in all, he perceives himself as completely different and alien from others. The obtained combination of schemas was similar to those from different studies (Damiano, Reece, Reid,
Atkins, \& Patton, 2015; Boone, Braet, Vandereycken, \& Claes, 2013; Deas, Power, Collin, Yellowlees, \& Grierson, 2011; Unoka, Tölgyes, Czobor, \& Simon, 2010), which indicates that, despite a relatively small study group, the revealed relations seem to be consistent with other studies.

The above convictions, especially deeply rooted, lead to seeking such an area where taking control and achieving successes are possible, as well as receiving support and broad acceptance from other patients, communicating in numerous forums about anorexia. Hence in this way the patient achieves a way to compensate for negative schemas and negative emotions related thereto. Therefore, anorexia brings a whole range of secondary illness-related benefits (Stochel \& Janas-Kozik, 2010), which allow one to cope with one's own worthlessness and distinctness. Thus, treating anorexia without changing these convictions, which it is a compensation of, seems to be (and often is) barely effective (Eder et al., 2007).

Hence the second research question was posed RQ2: Do the schemas change under the influence of the 
6-week therapy, and what is the nature of the changes? It seems that without work focused on schemas one cannot expect significant changes (Young et al., 2014; Calvete et al., 2013). The results from Table 1 (and their graphical presentation in Figure 1) indicate though that the majority of schemas are less intense during the second measurement, and most of these differences are statistically significant. It could mean that the therapeutic work, oriented (especially in its CBT part) at automated thoughts, negative convictions and emotions, questions and hence weakens them. Nonetheless, complete negation of consolidated convictions and replacing them with others requires not only time but also testing them in real life situations. The point is, working with schemas starts in accordance with typical cognitive therapy procedures, which the women followed, but later on it requires applying specific experiential techniques; according to Young, behavioral (i.e. tested in everyday life) introduction of new coping styles is the most significant and the longest process of all (Young et al., 2014). In the therapeutic program of the center in which this research project was carried out, neither this phase nor the experiential work phase exists. Therefore, the observed changes could be expected to be temporary and result only from cognitive questioning of automated thoughts and increase self-esteem. Nevertheless the change in intensity of some schemas by 3-4 points (Table 1) seems to be quite significant and indicates that there is a potential for change also when working using the classical CBT method. However, it is worth noting that the authors indicate quite unequivocally the relative stability of schemas during treatment in the follow-up studies (Renner, Lobbestael, Peeters, Arntz, \& Huibers, 2012), as well as their potential ability to predict recurrences (Malogiannis et al., 2014), which means that the therapy probably does not change the schemas combination, especially when it is not focused directly on changing them.

The presented research confirms these conclusions. A simple observation of the combination of the most severe schemas during the second measurement indicates minor changes in their structure. The most well-developed schema were unrelenting standards and abandonment, as during M1. The combination of the most intense schemas during the second measurement does not include social isolation and defectiveness; instead of them, negativism and approval-seeking became relatively strong. However, the average intensities of these schemas were very similar.

Multidimensional scaling presents changes in interrelations between the schemas. Scatter diagrams do not differ dramatically among each other, nevertheless they reveal some interesting relations. Due to the exploratory nature of this research and the small size of the study group, the authors decided not to name in a definite way the dimensions in the common area of the schemas. However, in order to conduct a preliminary analysis, it was assumed that the first dimension represented self-assessment from 'me-weak' (negative values) to 'me-strong' (positive values), and the second dimension represented emotions directed towards others (negative values) or to oneself (positive values).

During the first measurement, the vast majority of the schemas appeared on the weak side, mostly focused on self-oriented emotions (e.g. punitiveness, defectiveness, failure, inhibition, mistrust), but also directed towards others (e.g. abandonment, social isolation, unrelenting standards and approval-seeking) (Figure 2). Therefore, it can be concluded that this combination of schemas characterizes a person convinced that he is worse, destined to fail, incompetent, setting unreasonably high expectations he cannot meet. Such individuals concentrate a lot on such thinking; the emotions triggered by it are directed nearly equally towards oneself ('this is the way I am': failure, defectiveness, mistrust) and towards others ('this is the way I should be' - approval seeking, self-sacrifice, unrelenting standards, lack of self-control). On the 'stronger' side (dimension 1) there are definitely fewer schemas, and they group in the 'others' space (self-sacrifice, grandiosity) on the dimension self-others. It would imply that the 'stronger' side is actually the perception of what one owes others. Therefore it represents the image of a person convinced he is worse and weaker, who balances between being worse and showing others that he is better and can overcome his limitations. It is also a typical image of an anorectic (Jośko \& Kamecka-Krupa, 2007; Kozak \& Kozak, 2003).

During the second measurement, some of the schemas moved within their common space (Figure 3). The largest change could be observed in the case of the self-sacrifice schema, which moved from the space 'me-better' and orientation at others, towards weakness and self-oriented emotions. It could be concluded that the patients changed the way they perceived their non-fulfillment of their own needs for the sake of others. They stopped perceiving it as demonstration of their strength; instead, they began to recognize it as a symptom of their weakness and inability to cope. A similar relation was observed in the case of the enmeshment (entanglement) schema: pursuit of blurred, excessively close relations and maintaining them stopped being a factor confirming one's own strength, and turned into a proof of weakness. The case was similar with the grandiosity schema, which is currently considered to involve seeking confirmation in the eyes of others (lower values on dimension 2). The second measurement revealed that the patients' weakness is mostly due to their self-sacrifice and setting themselves excessively high standards, which they cannot meet. However, 
most of the schemas moved on dimension 1 more towards strength, which corresponds to the results of the tests of differences, which indicated a decrease in their intensity. The largest change of that kind (a shift between the two measurements on only one dimension: worse-better) occurred in the case of the defectiveness and social isolation schemas. The tests of differences confirm the significant change in their intensity; what is more, during the first measurement they were one of the most severe schemas, and during the second measurement they were not (see Table 1).

Apart from answering the research question, the above analyses allow us to make an assumption concerning the therapy: it might not be efficient in terms of changing schemas, yet it triggers changes which should be continued in order to achieve success. In the studies reported by Gustek, after 6 months of therapy only individuals working according to the cognitive paradigm continued it; these people achieved spectacular results compared to those receiving only dietary counseling (Gustek \& Jaworski, 2011). It means that the therapy of anorexia is sensible only when we reach to what lies underneath the disease.

Another research question was: RQ3: What are the relations between the schemas and the illness acceptance, and do they change with time? First and foremost, it should be noted that, as presented in Table 2, the patients increased their acceptance of illness in a statistically significant way. It means that they grew to accept limitations and consequences of the illness, which could result from the fact that they learned to accept the fact they were ill and perceive their problem more realistically, than through the prism of rationalizations. In addition, they began to recognize new ways of fulfilling themselves. However, the comparison of the calculated means and the reference groups presented by Juczyński indicated that even during the second measurement, the acceptance was relatively low (Juczyński, 2001). The relations between the acceptance of illness and schemas are negative; therefore the more intense the schemas, the lower is the acceptance. The strength of the observed correlations during the first measurement was moderate. Low acceptance is related primarily to the intense schemas of emotional deprivation, abandonment, defectiveness, incompetence, entanglement and subjugation. As the intensity of the schemas decreased during the second measurement, the acceptance of illness increased; furthermore, more schemas revealed correlations, and they were stronger. Nevertheless, it is hard to compare the above results to other research projects, as the acceptance of illness was discussed mostly with reference to somatic diseases. In addition, the interpretation of the result is questionable, because anorexia, which is an egosyntonic illness, is treated as a part of the self and accepted. Hence the research should be deepened and enriched with interviews, which was not done, and which is one of the study limitations, but also a direction to be explored in the future.

The last research question posed was: $R Q 4$ : What are the relations between the schemas and the perception of one's own physical and mental well-being and the subjective assessment of one's own life, and do these relations change under the influence of the therapy? It seems that the schemas should in fact not correlate with such variables as physical well-being; however, earlier studies (Mącik, 2015) revealed that there could be such a correlation.

The data presented in Table 2 indicate that only physical well-being changed significantly after the therapy - it was assessed as worse than during the first measurement. This could indicate that the patients realized the health consequences of anorexia and experienced them in the course of the therapy; however, other uncontrolled variables could have an impact on this result, e.g. physical tiredness with the everyday routine of staying in the center. Other analyzed variables increased slightly, but these changes were insignificant.

There were few correlations between physical and mental well-being and the schemas revealed during the first measurement (Table 3). Physical well-being correlates positively with the enmeshment and subjugation schemas; these correlations were moderately strong. It is an interesting relation, which would be worth confirming in further research, as well as explaining why higher intensity of these schemas leads to better assessment of one's physical well-being. Maybe it is related to the pursuit of a relationship and rationalization of one's mood related to this, alongside hiding one's actual state or secondary benefits, such as gaining acceptance from other individuals with a similar disorder (Stochel \& Janas-Kozik, 2010). During the second measurement, the schemas did not reveal any correlation with that variable, which could mean that in the course of the therapy the patients learned to differentiate between what results from their state of health, and what from their own self-convictions; however, these are only interpretative hypotheses to be verified in further research.

Mental well-being also had two significant correlations during the first measurement: with the defeat and self-sacrifice schemas. The defeat schema is related negatively to mental well-being, which is quite understandable. However, self-sacrifice correlates positively with mental well-being, which means that the more the patients sacrificed their needs for the sake of others, the better they felt. Referring to the aforementioned multidimensional scaling, it can be observed that self-sacrifice allowed the patients to feel better by doing something for others and suppressing their feeling of guilt at the same time, presenting themselves as perfectionists and good people, hence gaining attention and acceptance. 
This correlation was not revealed during the second measurement, which could be interpreted as a positive change. There are also some other correlations (all negative), which means that the patients learned to connect their mood with their self-convictions.

The last analyzed variable was the assessment of one's life so far. However, no relations between this variable and the schemas were found. This could imply the strongly egosyntonic nature of anorexia symptoms and life with this illness; apart from that, patients do not consider difficulties they experience to be something they could change which is a pathognomonic symptom of this disorder (Starzomska, 2008), and in addition hinders therapy (Young et al., 2014). Here it could be a signal that the changes the patients achieved may not have been fully internalized by them.

\section{CONCLUSIONS}

The research described above provided a positive empirical verification of Young's early maladaptive schemas theory. The schema combination, which was characteristic for the examined anorectics, matched their self-image and self-esteem as described in the literature of the subject. Changes in intensity and combination of schemas observed under the influence of therapy seem to have a reasonable justification. In addition they indicate that it is not only possible to work on the schema, but also it brings measurable benefits, such as changes in mood or acceptance of the illness, which creates new opportunities for further work.

The conducted studies have numerous limitations: first of all the study group was small and only one therapeutic method was analyzed. No qualitative study was conducted, which would definitely broaden the range of interpretative possibilities for the obtained data. Due to these reasons, the authors stopped at posing research questions, and the answers to them have the status of interpretative hypotheses. They may be a starting point for planning further, more in-depth research.

\section{REFERENCES}

Bator, E., Bronkowska, M., Ślepecki, D., \& Biernat, J. (2011). Anoreksja - przyczyny, przebieg, leczenie. Nowiny Lekarskie, 80, 184-191.

Boone, L., Braet, C., Vandereycken, W., \& Claes, L. (2013). Are maladaptive schema domains and perfectionism related to body image concerns in eating disorder patients? European Eating Disorders Review: The Journal of The Eating Disorders Association, 21, 45-51.

Brummett, B. R. (2008). Attachment style, early maladaptive schemas, coping self-efficacy, therapy al- liance and their influence on addiction severity in methadone-maintenance treatment. Dissertation Abstracts International, 68, 6952.

Calvete, E., Orue, I., \& González-Diez, Z. (2013). An examination of the structure and stability of early maladaptive schemas by means of the Young Schema Questionnaire-3. European Journal of Psychological Assessment, 29, 283-290.

Damiano, S. R., Reece, J., Reid, S., Atkins, L., \& Patton, G. (2015). Maladaptive schemas in adolescent females with anorexia nervosa and implications for treatment. Eating Behaviors, 16, 64-71.

Deas, S., Power, K., Collin, P., Yellowlees, A., \& Grierson, D. (2011). The relationship between disordered eating, perceived parenting, and perfectionistic schemas. Cognitive Therapy and Research, 35, 414-424.

Eder, P., Stawczyk, K., Lehmann, A., Jankowiak, M., \& Cichy, W. (2007). Czy i jak można zapobiegać zaburzeniom odżywiania wśród młodzieży - słów kilka o akcji informacyjnej dotyczącej anoreksji i bulimii organizowanej przez poznański oddział IFMSA-Poland [Is there a possibility to prevent eating disorders among young people - A piece of information about campaign concerning anorexia and bulimia organized by Poznan's department of IFMSA-Poland]. Nowiny Lekarskie, 76, 242-245.

Gustek, S., \& Jaworski, M. (2011). Znaczenie interwencji żywieniowej w psychoterapii poznawczo-behawioralnej w bulimii [The importance of nutrition intervention in cognitive-behavioral therapy (CBT) in bulimia]. Psychiatria i Psychoterapia, 7 (2-3), 7-21.

Hawke, L. D., \& Provencher, M. D. (2012). The Canadian French Young Schema Questionnaire: Confirmatory factor analysis and validation in clinical and nonclinical samples. Canadian Journal of Behavioural Science/Revue Canadienne Des Sciences Du Comportement, 44, 40-49.

Hoek, H. W. (1998). Planowanie systemu opieki zdrowotnej dla osób z zaburzeniami odżywiania na podstawie danych epidemiologicznych [Planning an eating disorder service on the basis of epidemiological data]. World Psychiatric Association, 173, 13.

Jośko, J., \& Kamecka-Krupa, J. (2007). Czynniki ryzyka anoreksji [Anorexia risk factors]. Problemy Higieny i Epidemiologii, 88, 254-258.

Juczyński, Z. (1999). Narzędzia pomiaru w psychologii zdrowia [Measures in health psychology]. Przeglad Psychologiczny, 42, 43-56.

Juczyński, Z. (2001). Narzędzia pomiaru w promocji i psychologii zdrowia [Measurements for health psychology and health promotion]. Warszawa: PTP.

Kozak, G., \& Kozak, A. (2003). Cechy osobowości i obraz siebie pacjentek z jadłowstrętem psychicznym (anorexia nervosa) [Personality traits and 
self-image in anorectic female patients]. Roczniki Psychologiczne, 6, 115-129.

Kriston, L., Schäfer, J., Jacob, G. A., Härter, M., \& Hölzel, L. P. (2013). Reliability and validity of the German Version of the Young Schema Questionnaire-Short Form 3 (YSQ-S3). European Journal of Psychological Assessment, 29, 205-212.

Malogiannis, I. A., Arntz, A., Spyropoulou, A., Tsartsara, E., Aggeli, A., Karveli, S., Vlavianou, M., Pehlivanidis, A., Papadimitriou, G. N., \& Zervas, I. (2014). Schema therapy for patients with chronic depression: A single case series study. Journal of Behavior Therapy \& Experimental Psychiatry, 45, 319-329.

Mącik, D. (2015). Wpływ wczesnych nieadaptacyjnych schematów na samoocenę i ocenę swojego życia. Badania porównawcze kobiet młodszych i starszych [The influence of the early maladaptive schemas on self-esteem and evaluation of one's own life. The comparison study of older and younger women]. Przegląd Psychologiczny (in print).

Muris, P. (2006). Maladaptive schemas in non-clinical adolescents: relations to perceived parental rearing behaviours, Big Five personality factors and psychopathological symptoms. Clinical Psychology \& Psychotherapy, 13, 405-413.

Palus, K. (2006). Etiopatogeneza i terapia zaburzeń odżywiania się w perspektywie rodzinnej [The etiopathogenesis and therapy of eating disorders in the family perspective]. Roczniki Socjologii Rodziny, XVII, 235-253.

Przewoźnik, D. A. (2013). Wybrane zagadnienia dotyczące neurobiologii jadłowstrętu psychicznego [Selected issues concerning the neurobiology of anorexia nervosa]. Neuropsychiatria i Neuropsychologia, 8, 118-122.

Renner, F., Lobbestael, J., Peeters, F., Arntz, A., \& Huibers, M. (2012). Early maladaptive schemas in depressed patients: stability and relation with depressive symptoms over the course of treatment. Journal of Affective Disorders, 136, 581-590.

Starzomska, M. (2008). Egosyntoniczność jako patognomoniczny objaw anoreksji [Egosyntonicity as a pathognomonic symptom of anorexia nervosa]. Psychoterapia, 146, 61-74.

Stochel, M., \& Janas-Kozik, M. (2010). Przyjaciółki wirtualnej Any - zjawisko proanoreksji w sieci internetowej [Friends of virtual Ana - the phenomenon of pro-anorexia in the Internet]. Psychiatria Polska, 44, 693-702.

Talarczyk, M. (2009). Godne życie... a zaburzenia odżywiania się [A dignified life and eating disorders]. Psychoterapia, 148, 77-88.

Unoka, Z., Tölgyes, T., Czobor, P., \& Simon, L. (2010). Eating disorder behavior and early maladaptive schemas in subgroups of eating disorders. The Journal of Nervous and Mental Disease, 198, 425-431.
Young, J. E. (1999). Cognitive therapy for personality disorders: A schema-focused approach ( $3^{\text {rd }}$ ed.). Sarasota, FL, US: Professional Resource Press/ Professional Resource Exchange.

Young, J. E., Klosko, J. S., \& Weishaar, M. E. (2014). Terapia schematów. Przewodnik praktyka [Schema therapy: a practitioner's guide]. Sopot: GWP.

Young, J. E., Rygh, J. L., Weinberger, A. D., \& Beck, A. T. (2008). Cognitive therapy for depression. In: D. H. Barlow (ed.), Clinical handbook of psychological disorders: A step-by-step treatment manual ( $4^{\text {th }}$ ed., pp. 250-305). New York, NY, US: Guilford Press. 